\title{
PENERAPAN DESA PEDULI GAMBUT DI DESA SAWAHAN KECAMATAN CERBON KABUPATEN BARITO KUALA
}

\author{
Achmad Jaelani dan Gusti Khairun Ni'mah \\ Fakultas Pertanian, Universitas Islam Kalimantan \\ Email : ach_jaelaniborneo@yahoo.com
}

\begin{abstract}
Sawahan Village is one of the Transmigration villages in the Cerbon sub-district, Barito Kuala district, South Kalimantan province. This village has a vast expanse of rice fields and $90 \%$ of the people work as farmers. Sawahan village has an area of 5,950 ha with productive land of 1,200 ha which is mostly in the form of peatland. The land of the sawahan village is located near the tidal river flow containing low $\mathrm{pH}$ with high acidity levels ranging from 3,5 to 4,5. Land in the area is a type of peat land (black brown), so that not all plants, livestock and fish can grow / live except plants, fish, livestock that can adapt to this condition. Peatlands have their own difficulties in managing them. Some fruit plants and horticulture can live after being adapted to the condition of the land for a long period of time but given a considerable amount of lime to overcome high acidity and disease resistance. With this, many transmigrant farmers have difficulty in handling the land because some species of plants and fish cannot develop properly. For this reason a new breakthrough is needed so that this problem can be overcome and farmers are able to plant crops, fish and livestock specific to peatlands. Some of the results of the Uniska Agriculture Faculty trial which tried several plants that were adaptive to the conditions of peatlands such as Kweni Anjir, Limau Kuit, Rambutan Antalagi and Kasturi. In addition to fruit trees, there are also horticultural plants that have been tried on these peatlands, namely long beans, purple eggplant, bitter melon, tiyung chili (very spicy mini chili). For fish there are fragrant fish (cork) and catfish. Whereas livestock with Alabio ducks are resistant to peatland conditions. In addition to fruit trees, there are also horticulture plants that have been tried on these peatlands, namely long beans, purple eggplant, bitter melon, tiyung chili. The problem in this activity is how farmers make efforts in transmigrant areas by selecting mina plants, fish and livestock that are suitable for cultivation on peatlands, how to cultivate mina-plants and livestock for peatland species to get maximum results and how to pioneer marketing efforts production so that it can really increase the income of transmigrant farmers in Sawahan Village, Barito Kuala Regency.
\end{abstract}

Keywords: villages that care about peat, integrated farming

ABSTRAK
Desa Sawahan adalah salah satu desa Transmigrasi di wilayah kecamatan Cerbon
kabupaten Barito Kuala provinsi Kalimantan Selatan. Desa ini mempunyai hamparan
sawah yang sangat luas dan masyarakatnya 90\% bekerja sebagai petani. Desa sawahan
memiliki luas wilayah5.950 Ha dengan lahan produktif sebesar 1.200 Ha yang sebagian
besar berupa lahan gambut.Lahan desa sawahan terletak di dekat aliran sungai pasang
surut yang mengandung pH rendah dengan tingkat keasaman tinggi berkisar antara 3,5-
4,5. Lahan didaerah tersebut termasuk jenis lahan gambut (berwarna coklat hitam),
sehingga lahan seperti ini tidak semua tanaman, ternak dan ikan bisa tumbuh/hidup
terkecuali dengan tanaman, ikan, ternak yang bisa beradaptasi dengan kondisi ini.Lahan


gambut memiliki kesulitan tersendiri dalam pengelolaanya. Beberapa tanaman buah maupun hortikultura dapat hidup setelah diadaptasikan dengan kondisisi lahan dalam jangka waktu yang lama namun diberi penambahan kapur yang cukup banyak untuk mengatasi keasaman yang tinggi dan tahan penyakit. Dengan hal tersebut banyak petani transmigran yang kesulitas dalam menangani lahan tersebut karena beberapa spesies tanaman maupun ikan tidak bisa berkembang dengan baik. Untuk hal tersebut diperlukan terobosan baru agar masalah ini bisa diatasi dan petani mampu menanam tanaman, ikan dan ternak yang spesifik lahan gambut. Beberapa hasil percobaan Fakultas Pertanian Uniska yang mencobakan beberapa tanaman yang adaptif dengan kondisi lahan gambut seperti Kweni Anjir, Limau Kuit, Rambutan Antalagi dan kasturi. Selain tanaman buah, juga terdapat tanaman hortikultura yang sudah dicobakan di lahan gambut ini adalah kacang panjang, terung ungu, pare, cabe tiyung (cabe mini yang sangat pedas). Untuk Ikan ada ikan haruan (gabus) dan patin. Sedangkan ternak ada itik Alabio yang tahan kondisi lahan gambut. Selain tanaman buah, juga terdapat tanaman hortikultura yang sudah dicobakan di lahan gambut ini adalah kacang panjang, terung ungu, pare, cabe tiyung. Permasalahan dalam kegiatan ini adalah bagaimana upaya petani di daerah transmigran dengan pemilihan mina tanaman, ikan dan ternak yang cocok untuk budidaya pada lahan gambut, bagaimana cara budidaya mina tanaman-ikan dan ternak spesisik lahan gambut agar diperoleh hasil yang maksimal dan bagaimana upaya perintisan pemasaran hasil produksi agar betul dapat meningkatkan pendapatan petani transmigran Desa Sawahan Kabupaten Barito Kuala

Kata Kunci : desa peduli gambut, pertanian terpadu

\section{PENDAHULUAN}

\section{Latar Belakang}

Desa Sawahan adalah salah satu desa Transmigrasi di wilayah kecamatan Cerbon kabupaten Barito Kuala provinsi Kalimantan Selatan. Desa ini mempunyai hamparan sawah yang sangat luas dan masyarakatnya 90\% bekerja sebagai petani. Desa sawahan memiliki luas wilayah 5.950 Ha dengan lahan produktif sebesar $1.200 \mathrm{Ha}$ yang sebagian besar berupa lahan gambut.Lahan desa sawahan terletak di dekat aliran sungai pasang surut yang mengandung $\mathrm{pH}$ rendah dengan tingkat keasaman tinggi berkisar antara 3,5 - 4,5. Lahan didaerah tersebut termasuk jenis lahan gambut (berwarna coklat hitam), sehingga lahan seperti ini tidak semua tanaman, ternak dan ikan bisa tumbuh/hidup terkecuali dengan tanaman, ikan, ternak yang bisa beradaptasi dengan kondisi ini.Lahan gambut memiliki kesulitan tersendiri dalam pengelolaanya.

Beberapa tanaman buah maupun hortikultura dapat hidup setelah diadaptasikan dengan kondisisi lahan dalam jangka waktu yang lama namun diberi penambahan kapur yang cukup banyak untuk mengatasi keasaman yang tinggi dan tahan penyakit. Dengan hal 
tersebut banyak petani transmigran yang kesulitas dalam menangani lahan tersebut karena beberapa spesies tanaman maupun ikan tidak bisa berkembang dengan baik. Untuk hal tersebut diperlukan terobosan baru agar masalah ini bisa diatasi dan petani mampu menanam tanaman, ikan dan ternak yang spesifik lahan gambut. Beberapa hasil percobaan Fakultas Pertanian Uniska yang mencobakan beberapa tanaman yang adaptif dengan kondisi lahan gambut seperti Kweni Anjir, Limau Kuit, Rambutan Antalagi dan kasturi. Selain tanaman buah, juga terdapat tanaman hortikultura yang sudah dicobakan di lahan gambut ini adalah kacang panjang, terung ungu, pare, cabe tiyung (cabe mini yang sangat pedas). Untuk Ikan ada ikan haruan (gabus) dan patin. Sedangkan ternak ada itik Alabio yang tahan kondisi lahan gambut. Selain tanaman buah, juga terdapat tanaman hortikultura yang sudah dicobakan di lahan gambut ini adalah kacang panjang, terung ungu, pare, cabe tiyung.

\section{Permasalahan}

Mitra yang diikutsertakan pada kegiatan Program Kemitraan Masyarakat (PKM) adalah Kelompok Tani Makmur yang berkedudukan di
Desa Sawahan Kecamatan Cerbon kabupaten Barito Kuala Kalimantan Selatan. Kelompok Tani Makmur berdiri pada tahun 2014 dengan anggota 15 orang yang beranggotakan Para Transmigran di Desa Sawahan. Usaha KTM ini adalah mengelola lahan gambut untuk usaha pertanianperkebunan dan peternakan. Luas tanah pekarangan 2 ha dan memanfaatkan pekarangannya untuk budidaya palawija dan peternakan peternakan kambing dan itik dengan rata-rata kepemilikan ternak 4-6 ekor untuk kambing dan 2030 ekor itik Alabio. Sehingga dengan kondisi tersebut pemanfaatan pekarangan lebih dapat dioptimalkan.

Kelompok Tani Makmur usaha khususnya adalah bertanam padi. Adapun panennya setiap 6 bulan. Pada saat musim lahan kering, maka ditanami tanaman palawija seperti jagung dan buah buahan. Adapun tanaman sayur juga dilakukan setelah palawija. Dipilihnya kelompok Tani Maju karya karena (1) anggota kelompok mitra ini mempunyai komitmen yang kuat untuk mengembangkan usahanya (wirausaha) bersedia menerima inovasi dan ipteks (2) memiliki komitmen yang kuat untuk maju, dan meningkatkan pendapatan 
keluarga (3) Luas areal pekarangan rumah yang dimiliki anggota kelompok transmigrasi adalah 2 ha (3) Anggota kelompok berkeinginan agar lahannya dilakukan system terpadu dengan pemeliharaan ternak. (4) Walaupun petani kesulitan dalam pemberian pakan segar, karena kandungan air yang asam sehingga peternak banyak yang mati.

\section{BAHAN DAN METODE}

\section{Waktu dan Tempat}

Kegiatan ini berlangsung mulai November 2018 hingga April 2019 dan bertempat di Desa Sawahan Kecamatan Cerbon Kabupaten Barito Kuala

\section{Metode Pelaksanaan Kegiatan}

Metode yang digunakan dalam kegiatan pengabdian ini sangat komprehensif, dimana kegiatan yang dibuat dan dilaksanakan dijalankan sesuai tahapan yang runut dan membantu petani/peternak atau peserta kegiatan memahami visi kegiatan dari awal hingga akhir berupa output optimalisasi lahan gambut untuk produksi pertanian. Selain itu konsep pemahaman tentang manfaat dan fungsi lahan gambut di introduksi secara deduktif. Metode yang dikembangkan pada pelaksanaan kegiatan adalah :
1. Penyuluhan model PRA (Participatory Rural Appraisal), dilakukan menggunakan modul pelatihan dihadiri oleh mentor dan peserta pelatihan yaitu petani/peternak di sekitar lokasi kegiatan. Mentor berasal dari pelaksana kegiatan dan nara sumber ahli. Modul penyuluhan yang diberikan dalam memberi pondasi dasar kegiatan ini adalah :

1) Pemilihan tanaman (sayuran dan buah-buahan) yang cocok dengan kondisi lahan gambut

2) Budidaya Itik Alabio pada lahan gambut mulai dari DOD hingga dewasa petelur

3) Sistem penjernihan air gambut

Kegiatan penyuluhan sepenuhnya dilakukan dengan secara aktif mengikut sertakan peserta dalam setiap topik yang dibicarakan dan diharapkan muncul banyak saran, tanggapan, pertanyaan dan pendapat dari sebanyak mungkin peserta (curah pendapat / brain storming). Hal ini dirasakan akan mampu menarik minat lebih tinggi peserta untuk selalu ingin tahu dan mempercepat proses adopsi teknologi yang disuluhkan. 
2. Demonstrasi (demo), dilakukan uji coba penanaman hortikultura dan buah-bahan dan pembuatan pupuk plus yang sesuai kondisi lahan gambut.

\section{Pelaksanaan Kegiatan}

Adapun tahapan pelaksanaan kegiatan pengabdian ini adalah sebagai berikut :

1. Persiapan
a. Survey lapangan
b. Mengurus perizinan kegiatan
c. Konsultasi kerja tim pelaksana pengabdian
d. Pemantapan jadwa kerja kegiatan
e. Menyiapkan bahan dan alat
f. Observasi ke lokasi kegiatan

2. Operasional di lapangan

a. Pemilihan tanaman yang cocok dengan kondisi lahan gambut, system peraian gambut, dan pemeliharaan itik.
b. Bimbingan, penyuluhan dan demontrasi
c. Evaluasi dan tindak lanjut

3. Penyusunan laporan kegiatan

a. Menyusun Konsep laporan

b. Menyusun konsep laporan Akhir

4. Penggandaan dan penyerahan laporan Akhir
a. Penggandaan laporan sesuai format yang ditentuka
b. Penyerahan laporan Akhir Pengabdian Kepada masyarakat kepada LP2M Uniska MAB

\section{HASIL DAN PEMBAHASAN}

\section{Analisis Evaluasi dan Hasil}

\section{Cara Pemeliharaan DOD Itik Alabio}

Berdasarkan hasil pelaksanaan kegiatan pengabdian / penyuluhan yang dilakukan tim pelaksana dapat diketahui bahwa $100 \%$ peserta mengalami permasalahan yang sama dalam pemeliharaan DOD itik alabio yakni tingginya angka mortalitas yang tentunya sangat berdampak pada rendahnya produktivitas ternak dan pada akhirnya pendapatan peternakpun menjadi rendah. Hal ini disebabkan karena masa-masa pemeliharaan awal bibit itik (DOD) adalah masa-masa yang sulit, terutama pada awal pemeliharaan sampai umur 1-2 minggu, padahal sebenarnya DOD sendiri mampu untuk bertahan tidak makan dan minum dalam jangka waktu 1-2 hari karena masih mempunyai cadangan makanan dalam tubuhnya. Namun tetap harus memperhatikan pakan dan minumnya karena akan berdampak baik dan jeleknya pada tahap pemeliharaan selanjutnya. 


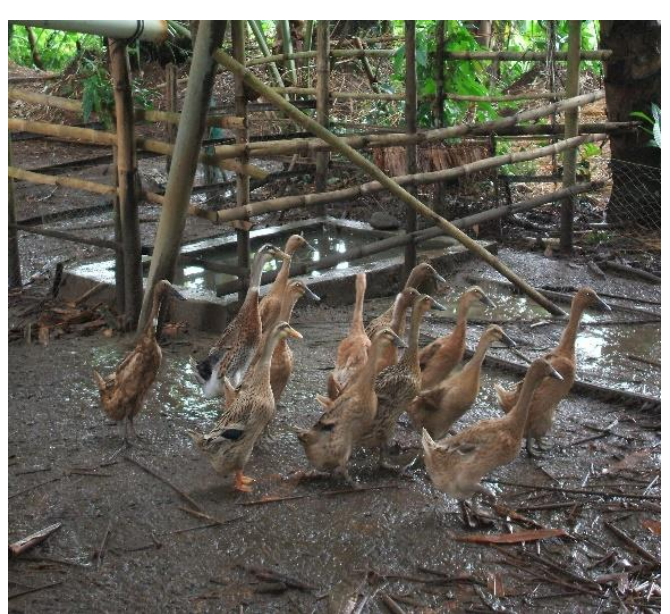

Gambar 1. Pemeliharaan itik Alabio mulai DOD hingga itik dewasa
Peserta sangat tertarik dan antusias dengan adanya kegiatan pengabdian ini, hal ini terlihat dari banyaknya permasalahan atau pertanyaan yang diajukan dan keinginan yang besar untuk mempelajari cara menekan angka mortalitas pada masa pemeliharaan DOD itik Alabio mulai dari cara penanganan DOD yang didatangkan dari tempat lain (membeli dari produsen bibit) sampai dengan penanganan DOD umur 1-2 minggu. Adapun beberapa cara penanganan yang perlu diberikan terhadap DOD yang didatangkan dari tempat lain antara lain

1. Pihak produsen bibit hanya mengirimkan DOD yang baru menetas (belum makan dan minum) karena DOD yang baru menetas bisa bertahan tidak makan dan minum sampai umur 2 hari

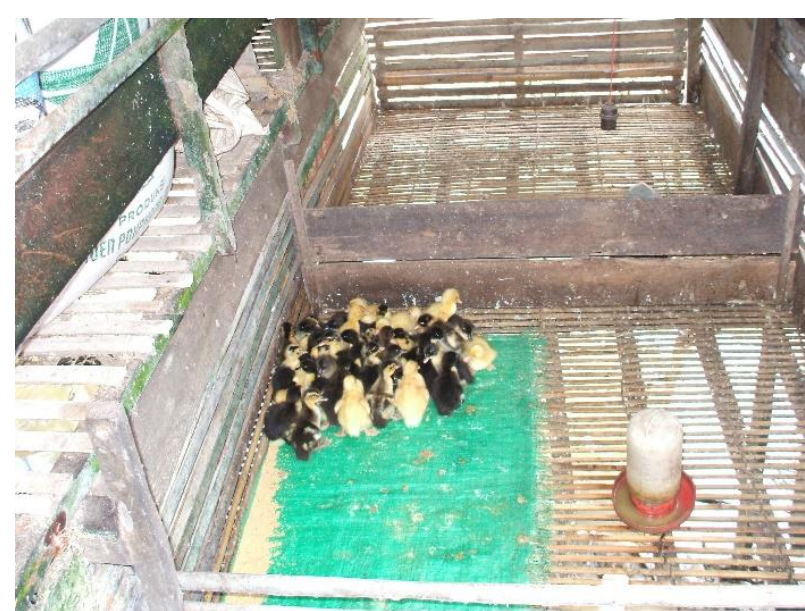

2. Dalam perjalanan sebaiknya ditambahkan kecambah sebagai ganti minumnya

3. Tidak mengirimkan DOD terlalu lama dari jam keberangkatan kendaraan

4. Pihak Ekspedisi diminta atau berinisiatif sendiri untuk menyiramkan air ketika DOD akan dimasukkan ke dalam pesawat untuk mengurangi hawa panas.

5. Segera ambil DOD di jasa ekspedisi yang ditunjuk ketika barang sudah sampai di tempat tujuan dan segera bawa pulang (ke kandang).

6. Setelah tiba di kandang cepat-cepat keluarkan DOD dari box, biarkan barang 20-30 menit kemudian beri minuman yang mengandung gula seperti larutan gula jawa/pasir, air susu kental manis agar stamina DOD pulih kembali. 
7. Setelah DOD diperkirakan sudah minum semua, ganti larutan gula/susu dengan vitamin seperti rhodivit, vitachick, sorbitol dll

8. Kurang lebih satu jam setelah kedatangan pakan sudah bisa diberikan. Biasanya pakan yang diberikan adalah pakan ayam ras pedaging periode starter dengan kadar protein sekitar $22 \%$.

Penanganan Itik periode starter (1-2 minggu)

Penanganan DOD umur 1-2 minggu antara lain sebagai berikut :

1. Anak itik umur 1-2 minggu menggunakan kandang open (kandang yang dilengkapi dengan pemanas) berupa boks berkaki yang sebelumnya disemprot dengan desinfektan.

2. Pemanas dinyalakan terus sampai umur 2 minggu dan perhatikan penyebaran anak di bawah lampu pemanas. Pemanas yang bisa digunakan antara lain pemanas lampu/dop, pemanas mitan (minyak tanah), pemanas LPG, dan pemanas dari briket batu bara. Jangan lupa untuk selalu menyesuaikan temperatur kandang dengan pertumbuhan anak itik.
3. Tidak lupa sekeliling kandang perlu ditutup dengan tirai plastik atau lainnya untuk menghindari angin yang masuk. Tirai plastik sebaiknya di buka pada siang hari dan ditutup pada malam hari, dilakukan mulai hari ke tiga atau ke empat. Pada umur 2 minggu tirai sudah bisa di buka semuanya dan anak sudah dapat di pindah ke kandang bawah (tanah) akan tetapi alas masih perlu diberi jerami malam hari suhu kandang tetap hangat.

4. Pakan sebaiknya diberikan sedikit demi sedikit dengan frekuensi sering. Kandungan protein pakan sebaiknya di atas 20\%. Untuk pemberian pakan secara basah/semi basah maka pemberiannya juga perlu dikontrol. Diusahakan pakan habis tidak lebih dari 60 menit setelah di berikan karena kalau tidak maka dikawatiran akan ditumbuhi jamur dan bisa menjadi sumber penyakit. Kesegaran pakan harus dijaga, hindari pemberian pakan itik yang sudah basi atau berjamur.

5. Pemberian vitamin dan antibiotika sangat dianjurkan pada periode ini karena untuk merangsang nafsu makan, keseragaman pertumbuhan dan pencegahan terhadap penyakit. 
6. Pemeliharaan umur ini sebaiknya jangan terlalu padat. Kepadatan kandang yang dianjurkan hanya 30 ekor/m2, karena kalau terlalu padat akan bisa menyebabkan itik saling berdekatan, saling tindih, udara yang pengap sehingga memacu timbulnya stress.

7. Menjaga agar sirkulasi udara dapat berjalan lancar dengan memberikan cukup ventilasi. Fungsinya adalah untuk mengatur keseimbangan kadar $\mathrm{CO} 2$ dan $\mathrm{O} 2$ di dalam kandang apalagi umur-umur ini sangat peka terhadap penyakit saluran pernafasan.

8. Usahakan kondisi kadang selalu bersih, kandang yang kotor akan mendatangkan penyakit yang dapat membunuh anak itik, buatlah lantai kandang yang berlubang (kawat ram atau bambu) sehingga kotoran itik bisa langsung jatuh, pastikan lubang yang ada tidak membuat kaki itik terjepit. Laksanakan program penyucihamaan kandang secara teratur dengan desinfektan yang aman.

9. Pemeliharaan sebaiknya yang seumur dan sejenis, hindari pemeliharaan DOD dengan itik remaja atau dewasa dalam satu kandang. Hal ini bertujuan untuk menghindari penularan penyakit.

\section{Pemeliharaan Itik Dewasa}

Menurut Hardjosworo dan Rukmiasih (2000) terdapat tiga sistem pemeliharaan itik yaitu pemeliharaan sistem gembala (tradisional), sistem semi intensif, dan pemeliharaan intensif.

Sistem gembala ditunjukan dengan tempat pemeliharaan itik berpindah-pindah untuk mencari tempat penggembalaan yang banyak tersedia pakannya, seperti sawah yang baru dipanen. Sistem semi intensif yaitu pemeliharaan dengan cara mengurung itik pada saat tertentu biasanya pada malam sampai pagi hari. Setelah itu itik dilepas di sekitar halaman kandang atau digembalakan di tempat penggembalaan yang dekat. Sistem pemeliharaan intensif yaitu pemeliharaan dengan cara itik selalu dikurung dalam kandang atau baterai.

Berdasarkan hasil kegiatan, dapat diketahui bahwa peternak dalam memelihara itik alabio masih menggunakan sistem pemeliharaan semi intensif yaitu pemeliharaan dengan cara mengurung itik pada saat tertentu biasanya pada malam sampai pagi hari. Setelah itu itik dilepas di sekitar halaman kandang atau digembalakan di 
tempat penggembalaan yang dekat. menggunakan sistem intensif karena Padahal sistem pemeliharaan yang banyak keutungannya dengan intensif cukup lebih baik jika menggunkan sistem intensif adalah itik dibandingkan sistem pemeliharaan dapat termonitor dengan mudahnya lainnya tidak terkecuali untuk peternak mengelola itik tanpa harus memikirkan itik di Indonesia juga banyak yang resiko tinggi.

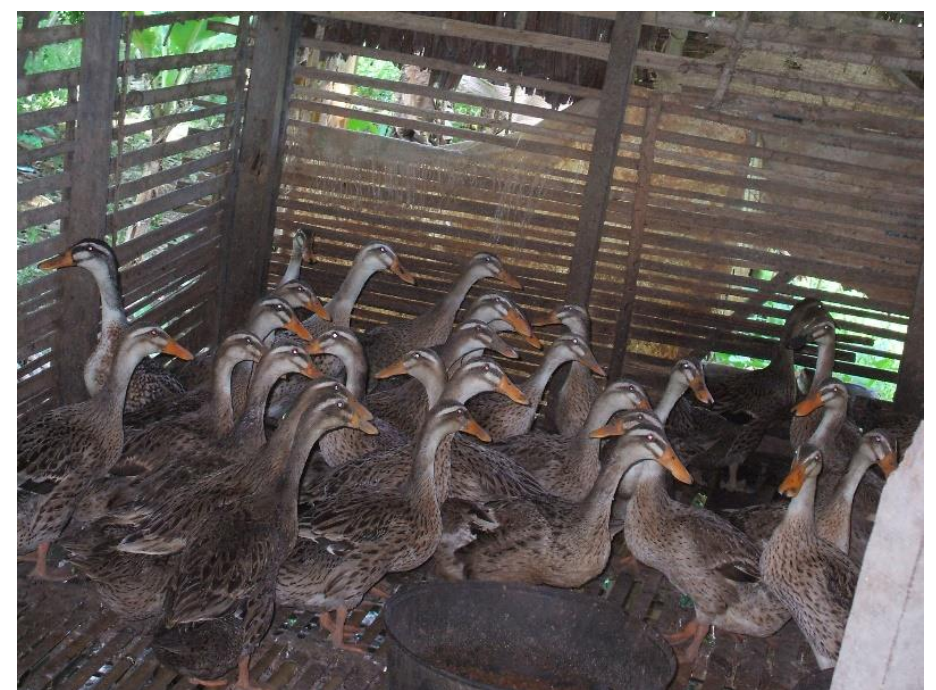

Gambar 2. Pemeliharaan itik pada kandang panggung di lahan gambut

Setelah dilakukan penyuluhan pemeliharaan itik alabio dari semi masyarakat/peternak mengetahui tentang berbagai jenis sistem yaitu intensif. Peserta sangat senang pemeliharaan itik alabio beserta dan Mereka berencana untuk kelemahan dan kelebihan masing- meningkatkan sistem pemeliharaan masing sistem tersebut. dalam rangka meningkatkan

Tim Pelaksana memberikan produktivitas ternaknya.
motivasi untuk meningkatkan sistem 


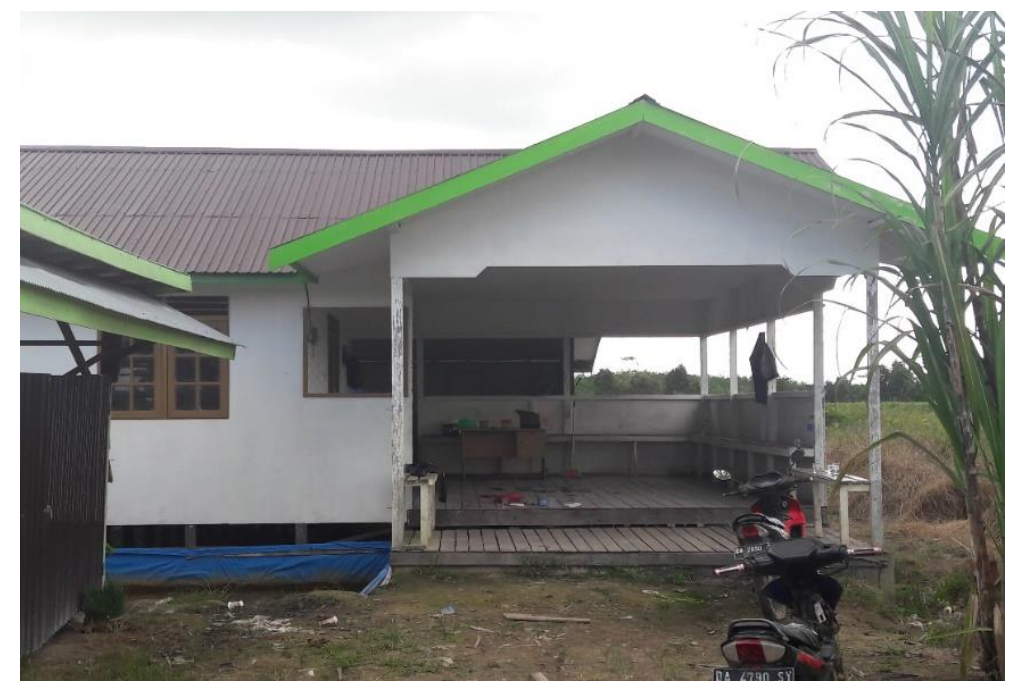

Gambar 3. Ruang pertemuan Kelompok Tani Makmur di Desa Sawahan Kecamatan Cerbon

\section{Penjernihan air gambut}

Kondisi air gambut yang berwarna gelap menunjukan tingkat keasaman air tersebut sangat masam, bisa mencapai $\mathrm{pH} 4-5$. Kondisi ini akan menyulitkan tanaman untuk tumbuh dan beerkembang kecuali yang sudah tahan dengan kondisi asam. Demikian pula dengan ternak itik Alabio yang kesulitan dalam mengkonsumsi air yang terlalu masam sehingga banyak itik yang masih muda mengalami kematian. Karena hal tersebut upaya penjernihan air mutlak dilakukan untuk tumbuhnya tanaman dan ternak serta bisa berkembangbiak dan berproduksi.
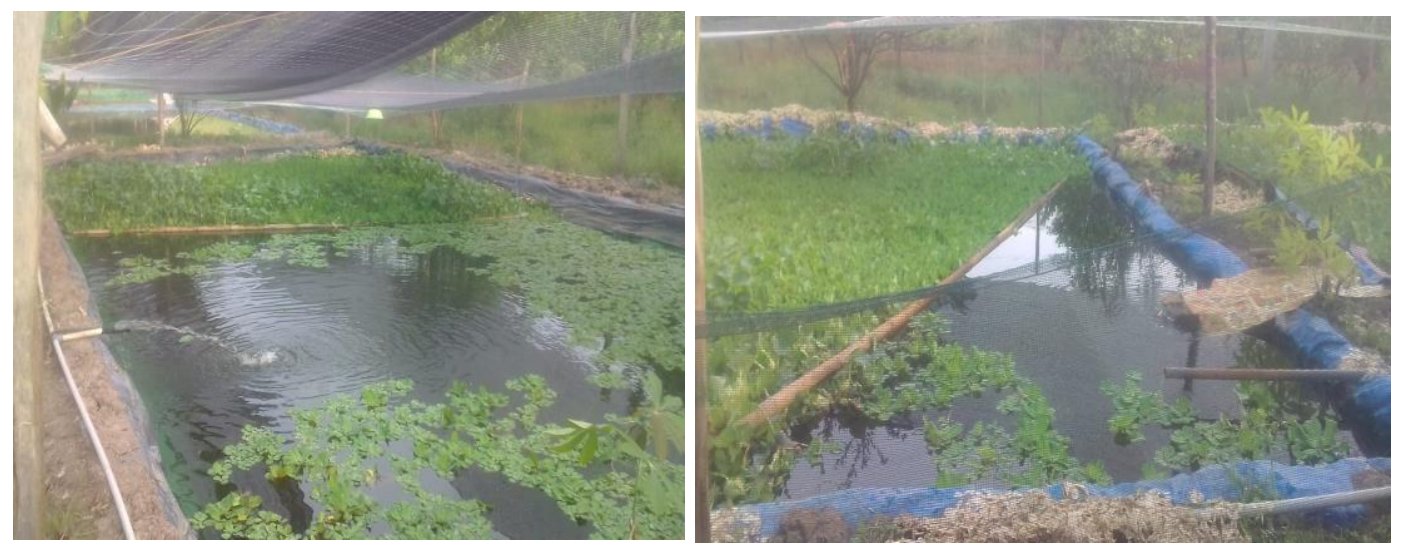

Gambar 4. Penjernihan dan pengurangan keaasaman air gambut dengan tanaman eceng gondok 


\section{Budidaya Tanaman Hortikultura}

Tanaman hortikultura yang dibudidayakan di Desa sawahan Kecamatan Cerbon kabupaten Baritokuala adalah tanaman yang sudah beradaptasi dengan kondisi gambut seperti Kacang panjang, cabe hyang, timun serta tanaman jeruk. Tanaman ini bisa dibudidayakan di lahangambut dengan hasil yang cukup baik. Namun dalam pengolahan lahanya sebelum ditanami bibit, tanahanya diberikan kapur untuk mengurangi keasaman. Disamping itu dengan adanya penjernihan air maka kondisi asamnya berkurang sehingga memberikan efek lingkungan yang lebih baik. Namun tata airnya seperti lahan gambut pada umumnya dadalah dengan membuat dua saluran air yang masuk dan keluar (bleaching).

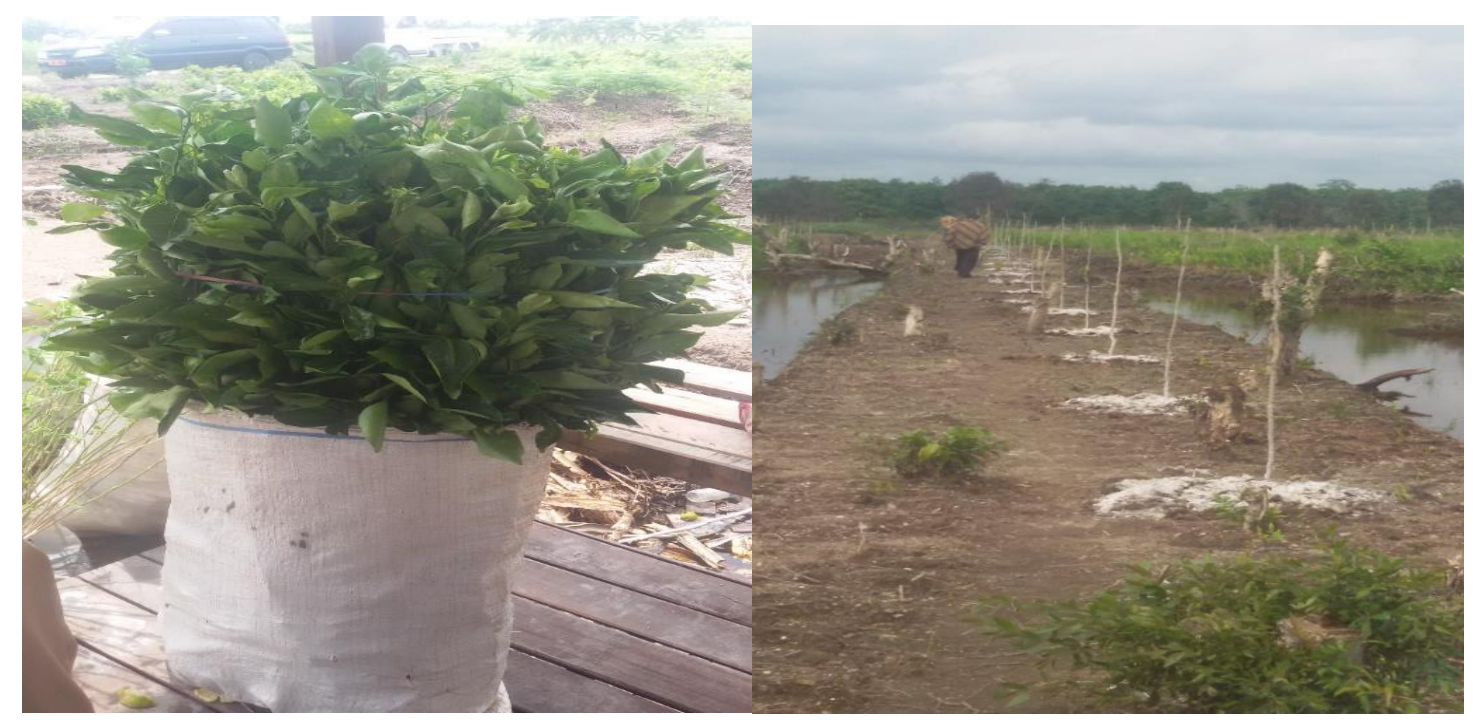

Gambar 5. Bibit buah jeruk dan Penanaman bibit Jeruk pada tanah gambut yang ditinggikan (bedengan)

Pada tanaman hortikultura dibua bedengan agar tanaman tidak terendam air gambut. Karena kalua kelamaan terendam maka akan mengurangi kuatan batang yang bisa menyebabkan rapuhnya batang karena kondisi air gambut yang masam. 

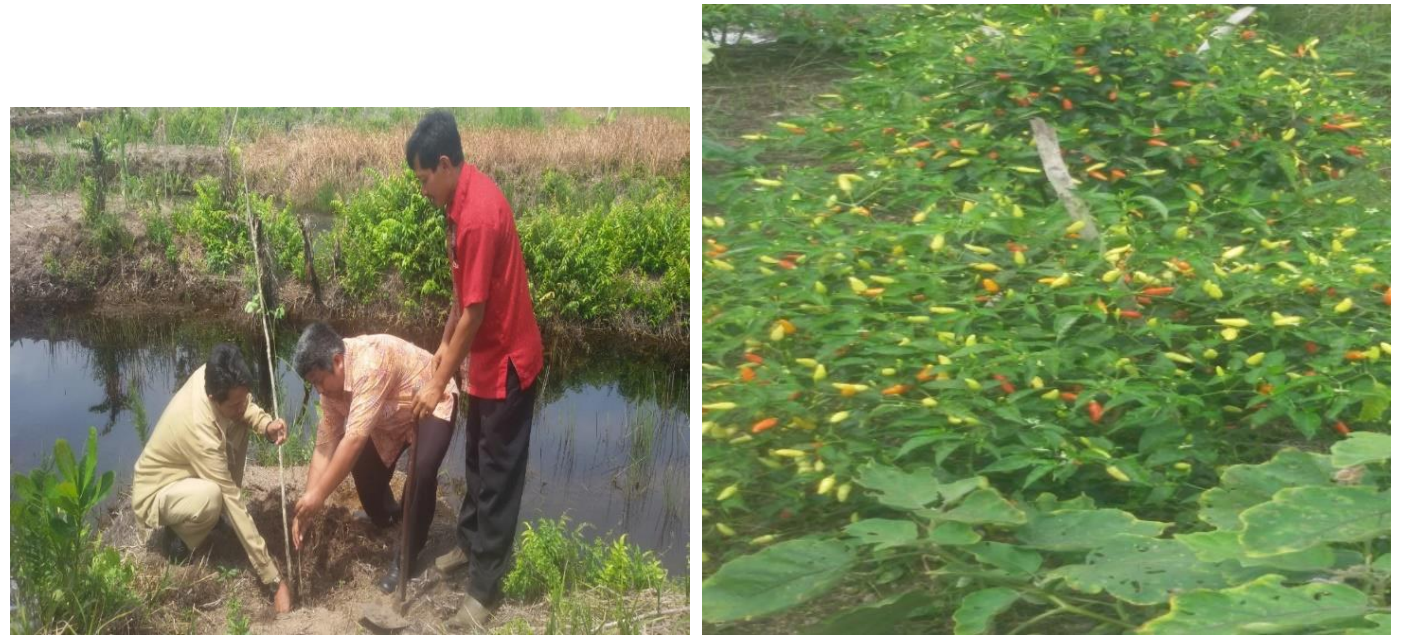

Gambar 6. Penanaman bibit jeruk di pinggir sungai lahan gambut Desa Sawahan dan pemanenan tanaman cabe rawit

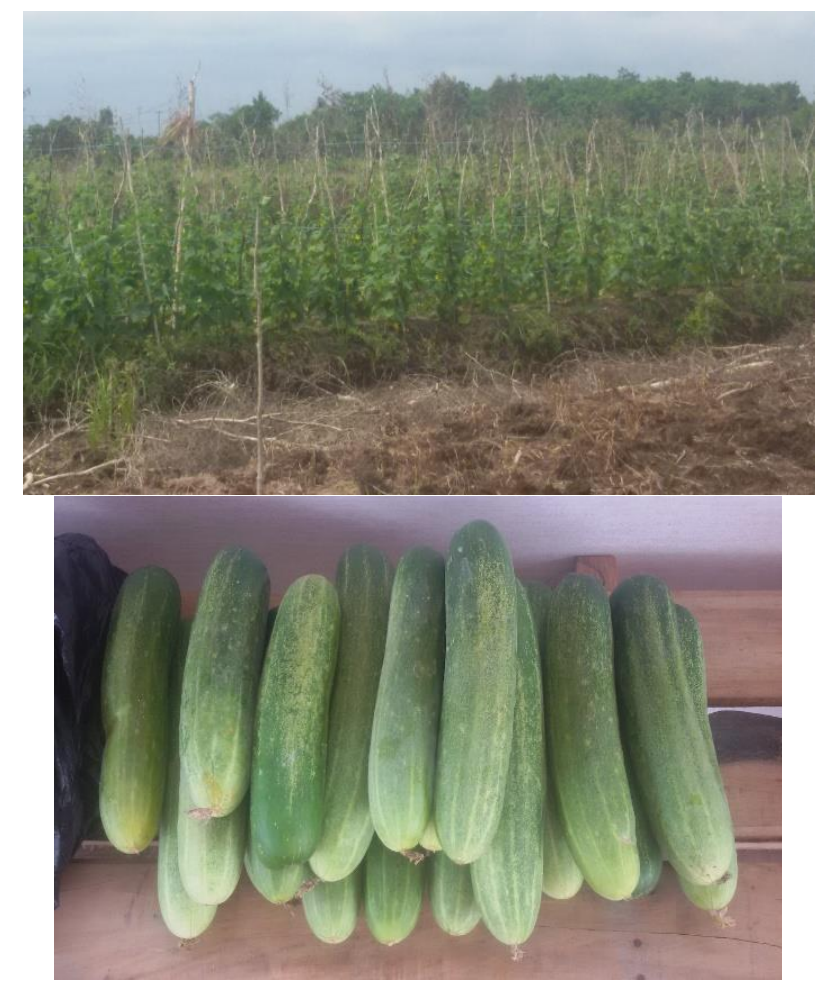

Gambar 7. Penanaman tanaman kacang panjang dan Hasil panen tanaman mentimum di Kelompok tani makmur

KESIMPULAN DAN SARAN

\section{Kesimpulan}

Desa Sawahan sebagai desa Peduli Gambut Di Kecamatan Cerbon Kabupaten Barito Kuala secara alami sudah melakukan pengelolaan lahan gambutmulai dari penataan air gambut agar damanfaatkan secara optimal, budidaya ternak itik Alabio yang familiar di lahan gambut serta 
pembudidayaan tanaman hortikultura yang sesuai kondisi gambut seperti cabai rawit hiyung, kacang panjang, timun dan jeruk siam.

\section{Saran}

1. Perlunya pemanfaatan gulma yang sangat melimpah di sekitar lahan gambut yang masih belum dioptimalkan untuk pakan ternak besar dengan mengintroduksi sentuhan teknologi pakan.

2. Perlunya terobosan pemasaran Hasil panen pertanian dan peternakan dalam bentuk perintisan jalur pemasaran dengan manajemen pemasaran yang lebih baik

\section{DAFTAR PUSTAKA}

Association of Official Analytical Chemist (AOAC). 1999. Official Methods of Analysis. Ed ke-16.Washington: AOAC International.

Badjoeri M dan Lukman 2002. Pemanfaatan tumbuhan kumpai dari danau semayang sebagai pakan sapi. Jurnal tropic Animal agriculture. 27 (2) : 125-133.

Badan Pusat Statistik Direktorat Jendral Tanaman Pangan. 2010. Luas lahan rawa di Indonesia, Departemen Pertanian. Jakarta.

$$
\begin{array}{cc}
\text { Badan Pusat Statistik } & .2011 . \\
\text { Kalimantan Selatan } & \text { Dalam } \\
\text { angka. BPS Kalsel } &
\end{array}
$$
Biren
Shah
Dan Avinash
Seth. Textbook
Of
Pharmacognosy
And
Phytochemistry. Elsevier Health
Sciences : Amsterdam. 2012. P384.

Cattelan, A.J., P.G. Hartel, and J.J. Fuhrmann. 1999. Screening for plant growth-promoting rhizobacteria to promote early soybean growth. Soil Sci.Soc.Am.J. 63: 1.670-1.680.

FNCA Biofertilizer Project Group. 2006. Biofertilizer Manual. Forum for Nuclear ooperation in Asia (FNCA). Japan Atomic Industrial Forum, Tokyo.

Fahriani A. dan Eviyati. 2008. Potensi Rumput Rawa sebagai pakan ruminansia : produksi , daya tampung dan kandungan fraksi seratnya. Jurnal Indonesia Tropik Animal Agriculture. N0 33(4) desember.

Faturrahman. 1988. Analisis Vegetasi dan Produktivitas Rumput Rawa di Kecamatan Danau Panggang Kabupaten Hulu Sungai Utara, Kalimantan Selatan. Karya Ilmiah. Fakultas Peternakan. Institut Pertanian Bogor. Bogor.

Haryuningtyas, D., Beriajaya, dan G.D. Gray.2001. Resistensi antelmintik golongan benzimidazole pada domba dan kambing di Indonesia. Seminar Nasional Teknologi Peternakan dan Veteriner, Pusat Penelitian dan Pengembangan Peternakan. Bogor, 17-18 September 2001.

Simanungkalit, R.D.M and R. Saraswati 1993. Application of biotechnology on biofertilizer production in Indonesia. pp. 4557. In S. Manuwoto, S. Sularso, and K. Syamsu (Eds.). Proc. 
Seminar on Biotechnology: Sustainable Agriculture and Alternative Solution for Food Crisis. PAU-Bioteknologi IPB, Bogor.

Simanungkalit, R.D.M and R. Saraswati 1993. Application of biotechnology on biofertilizer production in Indonesia. pp. 4557. In S. Manuwoto, S. Sularso, and K. Syamsu (Eds.). Proc. Seminar on Biotechnology: Sustainable Agriculture and Alternative Solution for Food Crisis. PAU-Bioteknologi IPB, Bogor.

Subba Rao, N.S. 1982. Biofertilizer in Agriculture. Oxford and IBH Publishing Co., New Delhi.

Larsen, M. 2000. Prospects for control ing animal parasitic nematodes by predacious micro fungi. Parasitology 120: S121-S131.

Musa, A.F. 1988. Mengenal Rumput Terapung Daerah Rawa Kalimantan Selatan. Majalah
Swadesi Peternakan Indonesia, Edisi Juni 1988. Jakarta.

Rohaeni, E.S., A. Darmawan, R. Qomariah, A.Hamdan Dan A.Subhan. 2005. Inventarisasi Dan Karakterisasi Kerbau Rawa Sebagai Plasma Nutfah. Laporan Hasil Pengkajian.Balai Pengkajian Teknologi Pertanian (BPTP) Kalimantan Selatan. Banjarbaru.

Steel, R. G. D. and J. H. Torrie. 1993. Prinsip dan Prosedur Statistik. Ed ke-2. Sumantri B, Penerjemah. Jakarta: Gramedia Pustaka Utama. Terjemahan

Urquhart, G.M., J. Armour, J.L. Duncan, A.M. Dunn, and F.W. Jennings. 1987. Veterinary Parasitology. Departement of Veterinary Parasitology, Faculty of Veterinary Medicine, The University of Glasgow, Scotland. Longman Scientific \& Technical. Published in USA by Churchill Livingstone Inc, New York. 